\title{
RACE, MILIEU, AND MOMENT IN “TITANIC" BY JAMES CAMERON: HISTORICAL APPROACH
}

\author{
Icha Sartika ${ }^{1}$ \\ Universitas Putera Batam, Batam, Kepri, Indonesia \\ pb171210013@upbatam.ac.id ${ }^{1}$ \\ Tomi Arianto ${ }^{2}$ \\ Universitas Putera Batam, Batam, Kepri, Indonesia \\ Tomi.arianto@puterabatam.ac.id ${ }^{2}$
}

\begin{abstract}
Literary criticism is defined as a science and try to investigate literary work with analyse and comparison. The purpose of this study is to get some information and to identify the race milieu and moment in literary work. Outlined Hipollyte Taine perspective in three concepts, namely (1) race, (2) Milieu, and (3) Moment. This phenomenon occurs in Titanic film by James Cameron. The researcher using Qualitative descriptive methods to analyse race, milieu and moment in Titanic film by James Cameron. The data collected by recording the data. Data analysed using Hippolyte Taine and Guerin theory for historical biographical approach. The result of analysis found that the disparity in the status of ship passengers for the poorer and upper classes is depicted in James Cameron's film Titanic as evidence of social class inequality. Because of his act of obtaining an award despite being in the lower class, Jack, as a class representative, does not have the right to be considered a person at the bottom. Mileu pits the position of social class against the community, which is backed up by the class division. Meanwhile, Moment is viewed through the lens of a social class that exists between the bourgeoisie and the proletariat, as evidenced by the numerous forms of discrimination discovered.
\end{abstract}

Keywords: Race Milieu and Moment, Film, Literary Criticism.

\section{INTRODUCTION}

Literature is the art of the language which has meaning. Literary work is an expression of personal human feelings of experiences, thoughts, ideas, enthusiasm, beliefs which are described in writing. According to Guerin (2005) said that "Literature is composition that tells the story, dramatize a situation, express emotions, analyse and advocates idea". It means that Literature is a work to tells about feelings or situations and then analyze them. 
One example or phenomenon of the literary criticism is historical biographical approach. The historical biographical approach is one of literary criticism that was introduced by Hippolyte Adolphe Taine. His term of "race, milieu, et moment" basically says that the historical biographical approach sees literary work as a reflection of its author's life and times or the life and times of the characters in the work, as stated in Guerin (2005).

The example of "race, milieu, et moment" can be found in Titanic Film by James Cameron. James Cameron is one of the most famous directors in the Hollywood film industry. $\mathrm{He}$ is a Canadian who was born in Ontario on August 16, 1954. Apart from being a director, he is also a producer, script writer and an entrepreneur. He is also famous as an underwater explorer. Many consider James Cameron to be one of the greatest directors of all time. Then he started a high budget film making project adapted from the true story of the sinking of the Titanic. The film, which was later released in 1997, was also able to be a huge success, even becoming the highest grossing film of all time at that time. Titanic also received 14 Academy Award nominations and won 11 of them, a record in Academy history. The great success of Titanic made James Cameron one of the top directors.

James Cameron's inspiration for making the Titanic film began with his interest in the wreck of the RMS Titanic. To him, Titanic was the "Mount Everest of the wreck." Cameron was also a hobbyist on sea expeditions. In fact, this is also the inspiration in making the Titanic. He dived into the Atlantic Ocean to see the original wreck of the Titanic and he wanted to convey the emotional message of the tragedy and thought that a love story interspersed with the tragedy of death was necessary to create the message. Production for this film began in 1995. A reconstruction of the Titanic was built at Playas de Rosarito, Baja California.

The Titanic film tells the sad tragedy of the RMS Titanic, the largest ship that sank in the North Atlantic Ocean on April 15, 1912. This British ship sank after hitting an iceberg on April 14, 1912 at around 23:40 local time during its maiden voyage from Southampton, England to New York City, America. This story was picked up in a film called Titanic which was released on December 19, 1997. Titanic stars are Kate Winslet, Leonardo DiCaprio, Billy Zane, Kathy Bates, and many more.

The Titanic film tells the love story of Rose and Jack who grew up on this biggest ship before sinking. 17-year-old Rose Dewitt Bukater was a passenger on the RMS Titanic with her mother, Ruth DeWitt Bukater, and her fiancé, Caledon Nathan Hockley, who was a successful businessman. The ship will sail from Southampton to New York. Rose is forced to become Cal's fiancé who is arranged by her mother for financial reasons and family honour. Rose, who doesn't love Cal, intends to commit suicide when the Titanic sails. A man named Jack who saw him then prevented Rose from committing suicide. Since that incident, the two of them became close and fell in love with each other. 194 minutes in duration, Titanic was directed and written by James Cameron.

Jack himself was a painter who had the opportunity to board the Titanic 
after winning a poker gambling. The love story of Jack and Rose is so happy that one day they have to go into big trouble because they are framed by a jealous Cal. Tragic events then began to occur when the starboard side of the ship hit a chunk of ice in the middle of the ocean. As a result, the ship began to slowly sink. Rose, who should have been able to immediately save herself with a lifeboat with her mother and fiance, decided to save Jack, who was handcuffed on the lower deck due to Cal's act. After struggling with great difficulty in trying to get Jack's hand off the post, the two then threw themselves into the sea with the other passengers. Both of them waited a long time on the plank in the cold Atlantic Ocean to get help from rescuers. Jack eventually died of hypothermia and Rose survived. Rose, who managed to survive, finally lived his life with memories with Jack.

\section{THEORETICAL REVIEW}

\subsection{Historical Biographical Approach}

There are some approaches which use to criticize literary work. One of the approaches is Historical Biographical approach, which is first invented by Hippolyte Adolphe Taine. As mentioned in Guerin (2005), historical biographical approach sees literary work chiefly as a reflection of its author's life and times or the life and times of the characters in the work.

\section{a. Race}

The word race comes from the French term "race", Latin radix which means "root". This term has been used since the 20th century in a biological sense to denote a genetically diverse human population with members who share the same phenotype. ${ }^{1}$ states that race is a group of roles, physical differences that serve as the basis for determining different roles, this understanding of race concerns biological aspects of "physical characteristics, skin color, body shape, etc." and social aspects related to roles and habits. It means that race is group of humans with the same physical characteristics.

b. Milieu

Locale (Milieu) describes how generalizations defined "races" to fit and explain individual behaviour or expressions. Local based analysis to find out the truth movie-like conditions, even if only for a moment. Like time, political situation and state of society

\section{c. Moment}

Moment is a socio-political situation at a certain period. The environment includes natural, climatic, and social conditions. This concept of Hippolyte Adolphe Taine regarding milieu then becomes the link that connects literary criticism with the social sciences. Taine's views, especially those expressed in the book History of English Literature, were considered by contemporary Swiss reader Amile to open new horizons that were different and the horizons of rigid atomics (structuralism) that developed at that time. It means that moment is facts that occur in the film that have similarities to the original story.

\section{d. Previous Research}

The author uses several works that have topics related to this topic as comparisons and references. Piscesco, P.O., \& Arianto, T. (2021) used a

\footnotetext{
${ }^{1}$ Banton (1967)
} 
historical approach to show the practice of Apartheid in a story entitled "ESCAPE FROM PRETORIA." The creation of Apartheid placed the black race under the control of the white race, and this behavior is acceptable in everyday culture. In contrast to Zakiyah, S. N., Machdalena, S., \& Fachrullah, T. A. (2020), in their analysis, they conducted research using a historical comparative linguistic approach in Sunda and Java. There are 49 data points in phonemic correspondence from 200 swadesh vocabulary data, which are separated into 12 correspondence sets. Nur Alifah, S. (2001) also analyses literature historically by presenting the phenomenon of Prince Dipenogoro's divination power in the novel Landung Simatupang. Butler's Cricket story related to floating identity was conducted by Pabiona, H. Y., and Arianto, T. (2021). The occurrence and phenomena of hybridity in the form of ambivalence and mimicry in the short story are used to determine the identity of the main character reflected in the story, based on Bhabha's definition of the term. In previous studies, researchers found similarities and differences. The similarity is that researchers use Taine's theory for race, the environment, and moments. The researcher, on the other hand, analyzes race, environment, and moments using drama scripts.

\section{RESEARCH METHOD}

Research design is framework in conducting research. In which there are procedures needed to obtain information to solve problems in research 2 . There are two kinds of research design; they are quantitative and qualitative research. Quantitative research is a systematic investigation of phenomena by collecting quantitative data and performing statistical, mathematical, or computational method. And qualitative is formal or objective and systematic to get information. The method used to explain relationship and cause affect relationship. In doing this research, the researcher uses qualitative research, it is applied to analyse race milieu and moment in Titanic film by James Cameron.

The object of research is very important to get scientific results. Researchers must be able to determine the object used in this study. In this study, the object is a form of race milieu and moment used by Titanic film by James Cameron. Then the data is all utterances that contain race milieu and moment in Titanic Film by James Cameron

In analyzing the data, the researcher applied race milleu and moment form theory proposed by 3 to analyze the race milieu and moment form. Theory by 4 to define historical biographical approach

\section{RESULT AND DISCUSSION}

4.1. Race

Race element in the film according to Taine referred to national characteristics or level that are typically found in works of art produced by the author. In the film of Titanic by James Cameron, Titanic passengers were divided into three classes, namely one, two and three. The third class was placed at the very bottom, then the

\footnotetext{
${ }^{3}$ Hippolyte Adolphe Taine

${ }^{4}$ Guerin
} 
second class, and the very top, the first class. In April 1912, Rose boarded the RMS Titanic as a first class passenger with her mother, Ruth DeWitt Bukater, and her fiancé, Caledon Nathan Hockley (Cal), a successful businessman in industry. Rose doesn't love Cal, but her mother forces her to marry him because of financial problems and family honor. At the same time, a man named Jack Dawson won a third-class ticket in a poker game and took part in Titanic's maiden voyage from Southampton to New York. It can be concluded that there are differences in social levels in the Titanic film.

Jack: "I'm not an idiot, I know how the world works. I've got ten bucks in my pocket, I have no nothing to offer you and I know it"

According to sentence above, jack realize he is not rich like rose.

\subsection{Milieu}

The milieu in the Titanic film by James Cameron the love story of Rose and Jack who grew up on the biggest ship before sinking. Then Rose was forced to become Cal's fiancé who was arranged by her mother. Unfortunately Rose did not love Cal and intended to commit suicide when the Titanic set sail. Then there was a man named Jack who saw him and prevented Rose from committing suicide. From then on, the two of them became close and fell in love with each other. It means thatThe situation change when rose met jack

\subsection{Moment}

In the film, Rose is the last survivor of the Titanic alive. In the film, Rose is told 101 years when the ship was found. In real life, the last survivor of the Titanic lived to be 97 years old in 2009. The passenger was named Milvina Dean. Dean was the youngest passenger on the Titanic. At that time, Dean went sailing with his parents and brother. the scene where Jack first meets Rose at the bow of the ship. in that scene, he recounts his experience when he fell into cold water while fishing.

He described it as "stabbed with a thousand knives".

The sentence turned out to be taken from an actual quote from one of the Titanic victims describing what the cold waters of the North Atlantic were like.

In the Titanic film, there is a touching incident where the musicians on the boat continue to play music to calm the passengers. even though they realized the ship was going to sink. turn out this is true from the real story.

\section{CONCLUSION}

Literature is a socio-cultural document that is used to see a phenomenon in society at that time. This is what is then termed in literary documentation as a reflection of an era. In the historical approach, literature is also considered as a reflection which contains historical elements inherent in that era. Literary criticism can see the reflection as a formulative way to describe a history. According to Swingwood (1986) this formulation is expressed in terms of Race, Milieu, and Moment. In James Cameron's film Titanic, it is found that inequality in social class can be seen from the difference in the status of ship passengers for the lower and upper classes. Jack as a class representative actually does not have the right to be a 


\section{sScience Humanity gournal}

person at the bottom because of his act of winning an award even though he is in the lower class. Mileu places the position of social class against the community, which is further confirmed by the division of classes. Meanwhile, Moment is seen from the social class that is insulated between the bourgeoisie and the proletariat, which is confirmed by the various discriminatory actions found.

\section{REFERENCES}

Abbot, Martin Lee and Jennifer McKinney, Understanding and Applying Research Design (New Jersey: Jhon Wiley and Sons Inc, 2013)

Creswell, J. W, Research Design, Qualitative, and Quantitative Approaches (London: Sage Publications, 1994)

Guerin, Wilfred. 2010. A Handbook of Critical Approaches to Literature. Sixth Edition. ISBN: 9780195394726. Exford University. Press

Klarer, Mario. 2005. An Introduction to Literary Studies. Routledge

Kothari, C.R., Research Methdology: Methods and Techniques (New. Delhi: New Age Publisher, 2004)

Nur Alifah, S. (2021). Representasi Kuasa Ramalan: Pangeran Dipenogoro Dan Akhir Tatanan
Lama Di Jawa 1785-1855 Karya

Peter Carey Dalam Aku

Dipenogoro! Oleh Landung

Simatupang. IdeBahasa, 3(1), 1-10. https://doi.org/10.37296/idebaha sa.v3i1.52

Pabiona, H. Y., \& Arianto, T. (2021). Floating Identity Reflected in Robert Olen Butler's Short Story "Cricket". Jurnal Basis, 8(2), 173180.

Link https://ejournal.upbatam.ac.id/in dex.php/basis/article/view/4108

Piscesco, P. O., \& Arianto, T. (2021). The Penomenon of Apartheid toward African People in "Escape from Pretoria": Historical Approach. IdeBahasa, 3(1), 39-48. https://doi.org/10.37296/idebaha sa.v3i1.56

Sudaryanto, Method Dan Teknik Analysis Bahasa (Yogyakarta: Duta Wacana University Press, 1993)

Swingewood, Alan. 1986. Sociological Poetics and Aesthetic Theory. London: Macmillan Press.

Zakiyah, S. N., Machdalena, S., \& Fachrullah, T. A. (2020). Korespondensi Fonemis Bahasa Sunda Dan Bahasa Jawa. IdeBahasa, 2(2), 121-132. https://doi.org/10.37296/idebaha sa.v2i2.44 